\title{
Annals
}

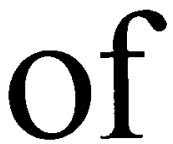

Botany

edited by

\section{J. F. Sutcliffe}

For the Annals of Botany

Company

\section{Publication}

January, March, May, July, September, November

\section{Subscription}

Volume 39,1975 : UK $£ 16 \cdot 50$, overseas $£ 18 \cdot 25 / \$ 43.50$, including postage

The Annals of Botany was founded in 1887 by a group of eminent botanists who formed a Company for the sole purpose of publishing the Annais. Over the years some of the most important research in botany has been published in this journal including Blackman's mathematical analysis of plant growth, Mason and Maskell's classical studies of phloem transport, and Gregory and Purvis's work on vernalization.

A distinctive feature of Annals of Botany is that while the material accepted for publication is critically reviewed its scope is unlimited, the only requirement being that it be pertinent to plants. With the development of specialist journals and changing fashions in research the balance of content has naturally changed from time to time. In keeping with modern trends a large portion of the articles published nowadays are physiologically orientated and many of them are concerned with some aspect of growth physiology. A separate "short communications" section is set aside for the rapid publication of brief articles of particular interest.

It is a paradox of scientific publication that as the number of specialist periodicals grows the usefulness of a general botanical journal increases. It enables specialists to keep abreast of research not only in their own field of study but also in related subjects and it is particularly useful for the non-specialist teacher or student who wishes to keep in touch with advances in knowledge over a wide area. Since its establishment, the Annals of Botany has developed into, and continues to be, one of the leading botanical journals of the world.

\section{Academic Press}

\section{London New York San Francisco}

A Subsidiary of Harcourt Brace Jovanovich, Publishers

24-28 Oval Road, London NW1, England

111 Fifth Avenue, New York, NY 10003, USA 


\section{INSTRUCTIONS FOR AUTHORS}

Papers and short notes from contributors anywhere in the world are welcome for consideration for publication in The Lichenologist and may be on any aspect of lichenology.

Manuscripts must be typewritten on foolscap or A4 size paper in double or treble spacing with 1 inch margins all round and should be submitted in duplicate to the Editor. Contributors should retain a copy of their paper for checking the proofs.

Line illustrations must be in black ink on stiff white card, preferably Bristol board.

As a guide to the layout of synonymy, references, etc., recent issues of the journal should be consulted. The spellings of locality names in Britain and abroad must follow those of the most recent editions of maps published by the Ordnance Survey and The Times Atlas of the World, respectively. Titles of periodicals should be abbreviated as in the fourth edition of the World List of Scientific Periodicals and its supplements. In lists of references the publisher and place of publication of books should be given; editions other than the first should be indicated.

Twenty-five reprints of original articles are supplied free. More may be purchased, as may reprints of other contributions such as book reviews. Reprints must be ordered when the author returns the proofs of his article.

Books dealing with any aspect of lichenology will be reviewed. Publishers wishing to have works reviewed in The Lichenologist should send them to the Assistant Editor in the first instance.

This journal is covered by Current Contents and Biological Abstracts.

\section{NOTICE}

While the Editor and Assistant Editor endeavour to check the accuracy of statements in contributions in as far as they are able, it should be emphasized that views expressed in papers in The Lichenologist are those of their authors and do not necessarily represent those of the British Lichen Society, Academic Press Inc. (London) Ltd, the Editor or the Assistant Editor.

\section{REFEREES}

The function of referees, whose names appear inside the front cover, is to assist members of the British Lichen Society in the identification of lichens. Specimens submitted should be adequate in size and well documented, including details of country, county or vice-county, borough or parish, precise locality and grid reference, altitude, date, habitat and ecology, notes, name of collector and collecting number. Identification should be attempted before sending material to a referee and details of spores and chemical reactions included where appropriate. Members wishing to send large numbers of specimens to a referee should first of all check that he is willing to name their collections for them. Return postage should always be included.

\section{MEMBERSHIP}

Membership of the British Lichen Society is open to all persons anywhere in the world interested in any aspect of lichenology. Subscriptions, due on joining and afterwards on 1 January each year, are: ordinary members, $£ 5$; junior associate members, $£ 1$; family members $£ 0.25$. Details of membership, activities of the Society and application forms may be obtained from the Secretary, Mr J. R. Laundon, Department of Botany, British Museum (Natural History), Cromwell Road, London, SW7 5BD, England. Members receive the Bulletin of the British Lichen Society and issues of The Lichenologist published in the year they join, and afterwards while they remain members of the Society, free of charge. Junior associate members do not receive The Lichenologist. 


\section{THE LICHENOLOGIST}

Fletcher, A.-Key for the identification of British marine and maritime lichens II. Calcareous and terricolous species

O'HaRe, G. P. and Williams, P.-Some effects of sulphur dioxide flow on lichens

Swinscow, T. D. V. and KROG, H.-The Usnea undulata aggregate in East Africa

Galloway, D. J. and Jørgensen, P. M.-Erioderma sorediatum, a new lichen from New Zealand

JAMES, P. W. and Henssen, A.-A new species of Psoroma with sorediate cephalodia

Swinscow, T. D. V. and KROG, H.-The genus Dermatocarpon in East Africa with an overlooked species in Britain

JAMES, P. W.-The genus Gyalideopsis Vězda in Britain

EARLAND-BENNETT, P. M.-Lecanora subaurea Zahlbr., new to the British Isles

Christiansen, M. S.-A combined alginate/carbowax method of making serial sections of lichens

HawksworTH, D. L.-Literature on air pollution and lichens III

\section{Field AND STUdy Note}

VICKERY, A. R.-The use of lichens in well-dressing

Distribution MAPS OF Lichens IN BRITAIN

Book Reviews

(C) British Lichen Society 1975

c/o Department of Botany, British Museum (Natural History),

Cromwell Road, London, SW7 5BD

Published twice a year for the British Lichen Society by Academic Press Inc. (London) Ltd at 24-28 Oval Road, London, NW1 7DX, England

Free to full members of the British Lichen Society

1975, Volume 7, 2 issues (April-October): Inland $£ 6.00$ including postage; Abroad £6.90 including postage. Subscription orders should be sent to Academic Press Inc. (London) Ltd, 24-28 Oval Road, London, NW1 7DX, England, except those from Canada, Central and South America and the U.S.A., which should be sent to Academic Press Inc., 111 Fifth Avenue, N.Y. 10003, U.S.A. Subscriptions from these countries: $\$ 16.00$ including postage. 